\title{
Correction to: The Effect of Hydroxy Metabolites of Clarithromycin to the Pharmacokinetic Parameters, and Determination of Hydroxy Metabolites Ratio of Clarithromycin
}

\author{
Durısehvar Unal ${ }^{1,2} \cdot$ Aysen Fenercıglu $^{3} \cdot$ Latıf Ozbay $^{1,2} \cdot$ Banu Ozkirim $^{1} \cdot$ Dılek Erol $^{1,2}$
}

Published online: 29 August 2020

(c) Springer Nature Switzerland AG 2020

\section{Correction to: \\ European Journal of Drug Metabolism and \\ Pharmacokinetics 34, 27-30 (2009) \\ https://doi.org/10.1007/BF03191380}

The following article was unintentionally published twice in European Journal of Drug Metabolism and Pharmacokinetics.

Unal D, et al. The effect of hydroxy metabolites of clarithromycin to the pharmacokinetic parameters, and determination of hydroxy metabolites ratio of clarithromycin.

The following should be considered the version of record and used for citation purposes:
Unal D et al. The effect of hydroxy metabolites of clarithromycin to the pharmacokinetic parameters, and determination of hydroxy metabolites ratio of clarithromycin. Eur J Drug Metab Pharmacokinet. 2009;34:27-30. https ://doi.org/10.1007/BF03191380.

The duplicate, Unal D et al. The effect of hydroxy metabolites of clarithromycin to the pharmacokinetic parameters, and determination of hydroxy metabolites ratio of clarithromycin. Eur J Drug Metab Pharmacokinet. 2008;33:243-246. https://doi.org/10.1007/BF03190879, is to be ignored.

Springer Nature apologizes to the readers of the journal for any confusion.

The original article can be found online at https://doi.org/10.1007/ BF03191380.

Durisehvar Unal

durisehvar@gmail.com

1 Yeditepe Health Service, GLP Laboratory and GCP Clinics, Kayisdagi, İstanbul, Turkey

2 Faculty of Pharmacy, Yeditepe University, Köftüncü Sokak. No: 1 Acibadem, 34178 Kadiköy, Istanbul, Turkey

3 Faculty of Medicine, Yeditepe University, Köftüncü Sokak. No: 1 Acibadem, 34178 Kadiköy, Istanbul, Turkey 